\title{
Penggunaan Model Kooperatif Tipe CIRC Berbasis Konstruktivisme Untuk Meningkatkan Kemampuan Komunikasi Matematis Siswa
}

\author{
Yusak I. Bien ${ }^{1)}$ \\ 1) Prodi Pendidikan Matematika STKIP SOE, NTT, Indonesia \\ E-mail:yusakbien87@gmail.com
}

\begin{abstract}
Abstrak. Sebagian besar siswa mempunyai kemampuan berhitung (komputasi) dalam menyelesaikan soal matematika tetapi bila diberikan soal cerita mereka mengalami kesulitan dalam menyelesaikan soal itu. Hal tersebut terindikasi bahwa kemampuan siswa dalam memahami dan merancang model matematika masih rendah, masalah tersebut terkait dengan masalah kemampuan komunikasi matematis. Penelitian ini bertujuan untuk mengetahui (1) ketuntasan kemampuan komunikasi matematis siswa menggunakan model pembelajaran kooperatif tipe CIRC berbasis konstruktivisme, (2) perbedaan kemampuan komunikasi matematis pada kedua kelas sampel yang dipilih berdasarkan kategori kelompok kemampuan komunikasi matematis awal siswa. Penelitian ini termasuk penelitian quasi experimental dengan pendekatan kuantitatif yang didesain dalam bentuk non-equivalent (pre-test and post-test control-group design). Hasil penelitian menunjukkan bahwa siswa yang diajarkan menggunakan model kooperatif tipe CIRC berbasis konstruktivisme mengalami ketuntasan baik individual maupun klasikal, kemampuan komunikasi matematis siswa pada kelas yang diajarkan menggunakan model kooperatif tipe CIRC berbasis konstruktivisme lebih baik dari siswa yang diajarkan tanpa menggunakan model tersebut berdasarkan kategori kemampuan komunikasi matematis awal siswa.
\end{abstract}

Kata Kunci: Kemampuan Komunikasi Matematis; Model CIRC; Konstruktivisme.

\section{PENDAHULUAN}

Salah satu tujuan mata pelajaran matematika di sekolah untuk semua jenjang pendidikan dasar dan menengah adalah agar siswa mampu mengkomunikasikan gagasan dengan simbol, tabel diagram atau media lain untuk memperjelas keadaan atau masalah. Matematika yang biasanya disajikan menggunakan simbol-simbol, istilahistilah, rumus, diagram, ataupun tabel, sehingga matematika juga dipandang sebagai suatu bahasa. [1] berpendapat bahwa matematika sebagai sebuah bahasa, matematika tidak hanya sekedar alat bantu berpikir, lebih dari alat untuk menemukan pola, menyelesaikan masalah, atau mengambil kesimpulan, tetapi matematika juga alat yang tak ternilai untuk mengkomunikasikan berbagai gagasan dengan jelas, akurat, dan ringkas. Selain itu [2] mencatat pula pentingnya komunikasi dalam matematika dengan mengatakan tidak akan ada matematika tanpa bahasa. Sementara matematika telah memiliki sendiri bahasa untuk komunikasi [3].

Ditegaskan pula oleh National Council of Teachers of Mathematics (NCTM) bahwa komunikasi adalah bagian penting dari matematika dan pendidikan matematika[4], sebab komunikasi merupakan cara berbagi ide dan mengklarifikasi pemahaman sehingga ide tersebut menjadi lebih bermakna. Komunikasi bisa mendukung belajar para siswa atas konsep-konsep matematis yang baru saat mereka memainkan peran dalam suatu situasi, mengambil, menggunakan obyek-obyek, memberikan laporan dan penjelasan-penjelasan lisan, menggunakan diagram, menulis, dan menggunakan simbol-simbol matematis.

Bangun ruang sisi datar yang terdiri dari kubus, balok, prisma dan limas merupakan salah satu materi yang diajarkan pada kelas VIII semester II. Materi ini terdiri dari objek berupa definisi, fakta, konsep, operasi dan prinsip sehingga menjadikan materi ini merupakan salah satu bagian yang penting. Berdasarkan wawancara dengan guru mata pelajaran matematika SMP Negeri 1 Soe terungkap bahwa kemampuan komunikasi matematis siswa VIII SMP Negeri 1 Soe yang terletak di kabupaten Timor Tengah Selatan (TTS) pada materi bangun ruang sisi datar masih rendah, selanjutnya dikatakan pula bahwa siswa mampu menyelesaikan soal matematika dalam bentuk 


\section{A - - Jurnal Pendidikan Matematika Indonesia \\ Volume 1 Nomor 2 bulan September 2016. Halaman 50 - 56 \\ p-ISSN: 2477-5967 e-ISSN: 2477-8443}

komputasi (angka), tetapi bila diberikan soal cerita (soal penerapan), siswa kesulitan dalam menyelesaikan soal tersebut. Sejalan dengan upaya perbaikan kualitas pembelajaran, penggunaan model pembelajaran dan pendekatan pembelajaran yang dipilih sangatlah penting agar dapat digunakan sebagai cara untuk mewujudkan rencana yang sudah disusun dalam bentuk kegiatan nyata dan praktis untuk mencapai tujuan pembelajaran. Proses kegiatan pembelajaran perlu diupayakan dalam rangka memperbaiki kemampuan komunikasi matematis siswa agar siswa dapat mengkomunikasikan ide matematika mereka. Hal tersebut dapat diupayakan dengan menerapkan model pembelajaran kooperatif di kelas.

Salah satu model pembelajaran kooperatif yang dapat digunakan adalah model pembelajaran kooperatif tipe Cooperative Integrated Reading and Composition atau yang biasa disingkat dengan CIRC. Model pembelajaran kooperatif CIRC menekankan bahwa siswa belajar secara berkelompok dan guru memberikan materi untuk dipahami oleh siswa. Dalam pembelajaran CIRC, setiap siswa bertanggung jawab terhadap tugas kelompok, setiap anggota kelompok saling mengeluarkan ideide untuk memahami suatu konsep dan meyelesaikan tugas, sehingga terbentuk pemahaman dan pengalaman belajar yang lama. Hasil penelitian [5] menemukan bahwa pembelajaran dengan model CIRC yang digunakan pada kelompok eksperimen lebih efektif untuk meningkatkan prestasi belajar siswa dan tingkat penyimpanan materi/daya ingat siswa bertahan lama daripada metode tradisional. Selain itu, pembelajaran matematika dengan menggunakan model pembelajaran kooperatif CIRC dapat meningkatkan kemampuan komunikasi matematika siswa [6].

Pembagian kelompok dalam pembelajaran dengan model CIRC mengajak siswa pada setiap kelompok agar dapat mengkonstruksi pengetahuan sendiri. Proses pembelajaran matematika akan bermakna apabila diterapkan pembelajaran yang berorientasi pada siswa. Maksudnya siswa mampu mengkonstruksi pengetahuannya sendiri berdasarkan pengalaman dalam kehidupan sehari- hari. Upaya siswa dalam mengkonstruksi pengetahuannya sendiri dikenal dengan istilah konstruktivisme. Dalam kelas konstruktivis seorang guru tidak mengajarkan kepada anak bagaimana menyelesaikan persoalan, namun mempresentasikan masalah dan mendorong siswa untuk menemukan cara mereka sendiri dalam menyelesaikan permasalahan [7]. Apabila siswa mengkonstruksi pengetahuannya sendiri dan mampu mengkomunikasikannya maka siswa tidak akan gampang melupakan konten (isi materi) yang dipelajarinya.

Berdasarkan uraian di atas, dalam mengatasi permasalahan komunikasi matematis siswa di sekolah SMP Negeri 1 Soe maka dibutuhkan model pembelajaran kooperatif tipe CIRC berbasis konstruktivisme. Penelitian ini bertujuan untuk mengetahui: (1) ketuntasan kemampuan komunikasi matematis siswa yang diajarkan menggunakan model kooperatif tipe CIRC berbasis konstruktivisme; (2) perbedaan kemampuan komunikasi matematis pada kelas yang diajarkan menggunakan model kooperatif tipe CIRC dengan siswa yang tidak mendapatkan model pembelajaran tersebut berdasarkan kategori kelompok kemampuan komunikasi matematis awal siswa.

Acikgoz dan Yaman mengatakan bahwa model pembelajaran CIRC merupakan salah satu model pembelajaran berbasis kerjasama, dirancang untuk mengembangkan membaca, menulis dan keterampilan bahasa lain pada pendidikan kelaskelas dasar dan menengah [5]. Teknik CIRC menyajikan struktur yang meningkatkan tidak hanya kesempatan untuk mengajar langsung dalam membaca dan menulis, tetapi juga penerapan komposisi teknik menulis. Walaupun demikian, CIRC telah berkembang bukan hanya dipakai pada pelajaran bahasa tetapi juga pelajaran eksak seperti pelajaran matematika.

Komunikasi matematis dapat diartikan sebagai suatu kemampuan siswa dalam menyampaikan sesuatu yang diketahuinya melalui peristiwa dialog atau saling hubungan yang terjadi di lingkungan kelas, dimana terjadi pengalihan pesan. Pesan yang dialihkan berisi tentang materi matematika yang dipelajari siswa, misalnya berupa konsep, rumus, atau strategi penyelesaian 
suatu masalah. Indikator kemampuan komunikasi matematis yang akan digunakan dalam penelitian ini adalah (1) menjelaskan ide dan situasi secara tulisan; (2) menyatakan gambar atau diagram ke dalam ide-ide matematika; (3) menyatakan situasi ke dalam model matematika/gambar; (4) menyatakan peristiwa sehari-hari dalam bahasa atau simbol matematika.

\section{METODE}

Penelitian ini menggunakan model quasiexperimental yang didesain dalam bentuk nonequivalent (pre-test and post-test) control-group design dengan pendekatan kuantitatif dan melibatkan dua kelas yakni kelas yang diajarkan menggunkan model kooperatif tipe CIRC (kelas eksperimen) dan kelas yang diajarkan tanpa menggunakan model tersebut (kelas kontrol). Pemilihan kelas menggunakan teknik cluster random sampling dengan memilih dua kelas dari sepuluh kelas pada siswa kelas VIII di SMP Negeri 1 Soe, Kabupaten Timor Tengah Selatan, Propinsi Nusa Tenggara Timur. Siswa kelas VIII10 terpilih sebagai kelas eksperimen dan siswa kelas VIII-8 terpilih sebagai kelas kontrol dengan sub-bab materi yang digunakan dalam penelitian ini adalah kubus dan balok.

Data dihimpun menggunakan tes berupa soal Tes Kemampuan Komunikasi Matematis (TKKM) siswa untuk mengungkap kemampuan komunikasi matematis siswa. Soal TKKM yang digunakan terdiri dari dua bagian yaitu pre-test dan post-test sebelum digunakan perlu diujicobakan dan dianalisis terlebih dahulu. Soal pre-tes digunakan untuk mengungkap kemampuan komunikasi matematis awal sebelum dikenai perlakuan penerapan model pembelajaran dan untuk pengkategorian kelompok kemampuan komunikasi matematis siswa. Pembagian kategori sesuai dengan Tabel 1[8].

TABEL 1

PengKategorian KelOMPOK KeMAMPUAN AwAl Siswa

\begin{tabular}{cc}
\hline Interval & Kelompok \\
\hline$x>\bar{x}+1 . S D$ & Atas \\
$\bar{x}-1 . S D \leq x \leq \bar{x}+1 . S D$ & Menengah \\
$x<\bar{x}-1 . S D$ & Bawah \\
\hline
\end{tabular}

dengan, $\bar{x}=\frac{\sum x}{N}$ dan $S D=\sqrt{\frac{\sum x^{2}}{N}-\frac{\left(\sum x\right)^{2}}{N}}$

Keterangan:

$x \quad$ : nilai pre-test siswa

$\bar{x} \quad$ : nilai rata-rata pre-test siswa

$S D \quad$ : standar deviasi nilai pre-test siswa

$N \quad$ : banyaknya siswa

Selain itu soal post-test digunakan untuk mengungkap kemampuan komunikasi matematis siswa di akhir penerapan model pembelajaran. Analisis uji coba butir soal yang digunakan dalam penelitian ini terdiri dari diuji validitas, reliabilitas, tingkat kesukaran dan daya pembeda.

Data yang telah dihimpun digunakan untuk menguji (1) ketuntasan siswa dalam pembelajaran dengan menggunakan model kooperatif tipe CIRC berbasis konstruktivisme yang terdiri dari ketuntasan individual dengan menggunakan uji $\mathrm{t}$ satu sampel dan ketuntasan klasikal menggunakan uji z; (2) perbedaan kemampuan komunikasi pada kedua kelas penelitian berdasarkan kategori kemampuan dengan menggunakan two way anova.

\section{HASIL DAN PEMBAHASAN}

Kemampuan awal siswa yang diperoleh dari hasil pre-test untuk pengkategorian kemampuan komunikasi matematis siswa secara ringkas ditunjukkan pada Tabel 2.

TABEL 2

PENYEBARAN SISWA BERDASARKAN KATEGORI KEMAMPUAN AWAL

\begin{tabular}{ccc}
\hline Kategori & \multicolumn{2}{c}{ Banyaknya siswa } \\
\cline { 2 - 3 } & Kelas eksperimen & Kelas kontrol \\
\hline Atas & 5 & 5 \\
Menengah & 21 & 20 \\
Bawah & 7 & 6 \\
\hline
\end{tabular}

Pengkategorian tersebut digunakan untuk mendapatkan gambaran lebih mendalam terkait hasil penelitian, kemampuan awal siswa yang diperoleh dari hasil pre-test dikategorikan dalam tiga kelompok yaitu kelompok atas, menengah dan bawah.

\section{A. Ketuntasan Belajar Siswa}

Hasil yang diperoleh terkait uji ketuntasan terhadap kemampuan komunikasi matematis siswa terdiri dari dua bagian yakni: 


\section{- - - Jurnal Pendidikan Matematika Indonesia \\ Volume 1 Nomor 2 bulan September 2016. Halaman 50 - 56 \\ p-ISSN: 2477-5967 e-ISSN: 2477-8443}

\section{1). Uji Ketuntasan Individual}

Rata-rata kemampuan komunikasi matematis siswa kelas eksperimen adalah 78,182 melampaui Kriteria Ketuntasan Minimal (KKM) kemampuan komunikasi matematis yang ditentukan yaitu 70 . Ketuntasan individual secara signifikan ditentukan berdasarkan perbandingan $t_{\text {hitung }}$ terhadap $t_{\text {tabel }}$ pada uji $t$ satu sampel dengan hipotesis sebagai berikut.

$\mathrm{H}_{0}: \mu \leq 70$ (rataan kemampuan komunikasi matematis siswa tidak melampaui 70)

$\mathrm{H}_{1}: \mu>70$ (rataan kemampuan komunikasi matematis siswa melampaui 70)

Nilai $t_{\text {hitung }}=5,702$ selanjutnya dibandingkan dengan harga $t_{\text {tabel }}$ dengan derajat kebebasan $(\mathrm{dk})$ $=\mathrm{n}-1=33-1=32$ dan taraf kesalahan 5\% yaitu 2,036. Karena $t$ hitung $>t$ tabel berarti Ho ditolak dan menerima $\mathrm{H}_{1}$. Oleh karena itu dapat disimpulkan bahwa nilai rata-rata kemampuan komunikasi matematis siswa pada kelas yang diajarkan menggunakan model kooperatif tipe CIRC melampaui rata-rata asumsi populasi yang ditetapkan yakni 70.

\section{2). Uji Ketuntasan Individual}

Data TKKM berdasarkan hasil post-test yang diperoleh sebanyak 30 siswa dari 33 siswa pada kelas eksperimen memperoleh nilai lebih besar dari KKM yang ditentukan yakni 70 atau sebesar 90,9 persen. Hal ini berarti pencapaian kemampuan komunikasi matematis siswa yang mencapai KKM secara klasikal sebesar 90,9 persen lebih dari proporsi ketuntasan yang ditargetkan yakni 75 persen. Ketuntasan klasikal secara signifikan ditentukan berdasarkan perbandingan zhitung terhadap $z_{\text {tabel }}$ pada uji proporsi dengan hipotesis sebagai berikut:

$\mathrm{H}_{0}: \mu \leq 75 \%$ (tidak lebih dari $75 \%$ siswa yang mendapat nilai TKKM minimal 70)

$\mathrm{H}_{1}: \mu>75 \%$ (lebih dari $75 \%$ siswa yang mendapat nilai TKKM minimal 70)

Nilai $z_{\text {hitung }}=2,19$ selanjutnya dibandingkan dengan harga $z_{\text {tabel }}$ dengan taraf kesalahan $5 \%$ yaitu 1,64. Karena zhitung $>\mathrm{z}_{\text {tabel }}$ berarti Ho ditolak dan menerima $\mathrm{H}_{1}$ yang berarti siswa yang mendapat nilai tes kemampuan komunikasi matematis (TKKM) minimal 70 lebih dari $75 \%$.
Hasil pengujian hipotesis kedua uji ketuntasan menunjukkan bahwa nilai rata-rata kemampuan komunikasi matematis siswa pada kelas yang diajarkan menggunakan model kooperatif tipe CIRC berbasis konstruktivisme melampaui ratarata asumsi populasi yang ditetapkan yakni 70 dan siswa yang mendapat nilai tes kemampuan komunikasi matematis (TKKM) minimal 70 lebih dari $75 \%$. Dengan demikian dapat disimpulkan bahwa kemampuan komunikasi matematis siswa pada kelas yang mendapatkan model pembelajaran CIRC berbasis konstruktivisme dapat mencapai ketuntasan minimal.

\section{B. Uji Beda Kemampuan Komunikasi Matematis Siswa}

Uji beda dengan two way anova yang digunakan untuk menentukan perbedaan kemampuan komunikasi matematis siswa pada kedua kelas berdasarkan kategori kelompok kemampuan atas, menengah dan bawah, dengan beberapa uji sebagai berikut:

\section{1). Uji Banding Baris}

Uji banding baris dalam penelitian ini terkait dengan membandingkan kemampuan komunikasi matematis pada kedua kelas penelitian. Hipotesis yang diuji sebagai berikut:

$\mathrm{H}_{\mathrm{o}}: \mu_{1}=\mu_{2}$ (rataan kelas eksperimen dan kelas kontrol adalah sama)

$\mathrm{H}_{1}: \mu_{1} \neq \mu_{2}$ (rataan kelas eksperimen dan kelas kontrol tidak sama)

Proses pengujian menggunakan program SPSS dengan menghasilkan output pada Tabel 3. Berdasarkan output pada Tabel 3, tampak bahwa variabel kelas memiliki nilai sig $=0,001=0,1 \%<$ $5 \%$ maka $\mathrm{H}_{0}$ diterima yang berarti rataan kemampuan komunikasi untuk kelas eksperimen dan kelas kontrol setelah pembelajaran adalah tidak sama atau berbeda. 
TABEL 3

UJI BEDA POST-TEST TKKM

\begin{tabular}{lrrrrr}
\hline & $\begin{array}{l}\text { Type III } \\
\text { Sum of } \\
\text { Squares }\end{array}$ & \multicolumn{5}{c}{$\begin{array}{c}\text { Mean } \\
\text { Square }\end{array}$} & \multicolumn{1}{c}{ F } & \multicolumn{1}{c}{ Sig. } \\
\hline $\begin{array}{l}\text { Corrected } \\
\text { Model }\end{array}$ & $2855,890(a)$ & 5 & 571,178 & 15,323 & 0,000 \\
Intercept & 271293,917 & 1 & 271293,91 & 7277,8 & 0,000 \\
Kelas & 435,435 & 1 & 435,435 & 11,681 & 0,001 \\
Kategori & 2104,449 & 2 & 1052,225 & 28,227 & 0,000 \\
kelas * & 18,107 & 2 & 9,054 & 0,243 & 0,785 \\
kategori & 2236,595 & 60 & 37,277 & & \\
Error & 374844,000 & 66 & & & \\
Total & 5092,485 & 65 & & & \\
Corrected & & & & & \\
Total & & & & & \\
\hline
\end{tabular}

\section{2). Uji Banding Kolom}

Uji banding kolom dalam penelitian ini terkait dengan membandingkan kemampuan komunikasi matematis berdasarkan kategori kelompok kemampuan pada kedua kelas penelitian. Hipotesis untuk uji banding kolom adalah sebagai berikut:

$\mathrm{H}_{\mathrm{o}}: \mu_{1}=\mu_{2}=\mu_{3}$ (rataan kemampuan komunikasi untuk kelompok atas, tengah dan bawah adalah sama)

$\mathrm{H}_{1}$ : (salah satu rataan berbeda)

Berdasarkan output pada Tabel 3 tampak bahwa untuk variabel kategori diperoleh nilai sig = $0,000=0 \%<5 \%$ maka $\mathrm{H}_{0}$ ditolak atau menerima $\mathrm{H}_{1}$ yang berarti rataan kemampuan komunikasi matematis dari ketiga kategori kelompok salah satunya berbeda. Oleh karena itu, dilakukan uji lanjut post hoc untuk melihat perbedaan yang terjadi.

Berdasarkan output pada Tabel 4 tampak bahwa perpaduan sampel kelompok atas dan menengah, atas dan bawah memiliki nilai signifikansi $\quad 0,000=0 \%<5 \%$ serta kelompok menengah dan bawah memiliki nilai signifikansi $0,004=0,4 \%<5 \%$. Nilai signifikansi perpaduan masing-masing sampel kurang dari 5\%. Oleh karena itu, kemampuan komunikasi matematis pada kelompok atas, menengah dan bawah semuanya berbeda.

Setelah mengetahui perbedaan kemampuan siswa setiap kategori kelompok kemampuan pada kedua kelas penelitian, selanjutnya membandingkan kemampuan berdasarkan setiap kelompok. Pada Tabel 3, tampak bahwa nilai $F_{\text {kelas*kategori sebesar 0,243 dengan signifikansi }}$ $0,785=78,5 \%$ yang jauh lebih besar dari $5 \%$, hal ini menunjukkan bahwa perbedaan antara selisih kemampuan komunikasi matematis siswa kelas eksperimen dan kelas kontrol pada kelompok atas, kelompok menengah, dan kelompok bawah tidak signifikan. Ini berarti bahwa kelas eksperimen lebih baik daripada kelas kontrol untuk semua kelompok, jadi kelas eksperimen yang berupa pembelajaran dengan model kooperatif tipe CIRC berbasis konstruktivisme dapat digunakan untuk meningkatkan kemampuan komunikasi matematis pada semua kelompok siswa.

\begin{tabular}{|c|c|c|c|c|c|c|c|}
\hline & & & $\begin{array}{r}\text { TAB } \\
\text { UJI POST H }\end{array}$ & $\begin{array}{l}\text { EL } 4 \\
\text { OC TKKN }\end{array}$ & & & \\
\hline & \multirow[t]{2}{*}{$\begin{array}{l}\text { (I) } \\
\text { kolom }\end{array}$} & \multirow[t]{2}{*}{$\begin{array}{l}(\mathbf{J}) \\
\text { kolom }\end{array}$} & \multirow[t]{2}{*}{$\begin{array}{c}\text { Mean } \\
\text { Difference (I- } \\
\text { J) }\end{array}$} & \multirow[t]{2}{*}{ Std. Error } & \multirow[t]{2}{*}{ Sig. } & \multicolumn{2}{|c|}{ 95\% Confidence Interval } \\
\hline & & & & & & $\begin{array}{l}\text { Upper } \\
\text { Bound }\end{array}$ & $\begin{array}{l}\text { Lower } \\
\text { Bound }\end{array}$ \\
\hline \multirow{6}{*}{ LSD } & \multirow{2}{*}{ Atas } & Tengah & $12,1190(*)$ & 1,99805 &, 000 & 8,1223 & 16,1158 \\
\hline & & Bawah & $18,0833(*)$ & 2,49201 &, 000 & 13,0986 & 23,0681 \\
\hline & \multirow[t]{2}{*}{ tengah } & Atas & $-12,1190\left(^{*}\right)$ & 1,99805 &, 000 & $-16,1158$ & $-8,1223$ \\
\hline & & Bawah & $5,9643(*)$ & 1,99805 &, 004 & 1,9676 & 9,9610 \\
\hline & \multirow[t]{2}{*}{ bawah } & Atas & $-18,0833(*)$ & 2,49201 & 000 & $-23,0681$ & $-13,0986$ \\
\hline & & Tengah & $\left.-5,96433^{*}\right)$ & 1,99805 & 004 & $-9,9610$ & $-1,9676$ \\
\hline
\end{tabular}

Kemampuan komunikasi matematis siswa pada hasil post-test antara kelas eksperimen dan kelas kontrol berdasarkan kategori kelompok siswa secara lebih jelas dapat dilihat pada Gambar 1.

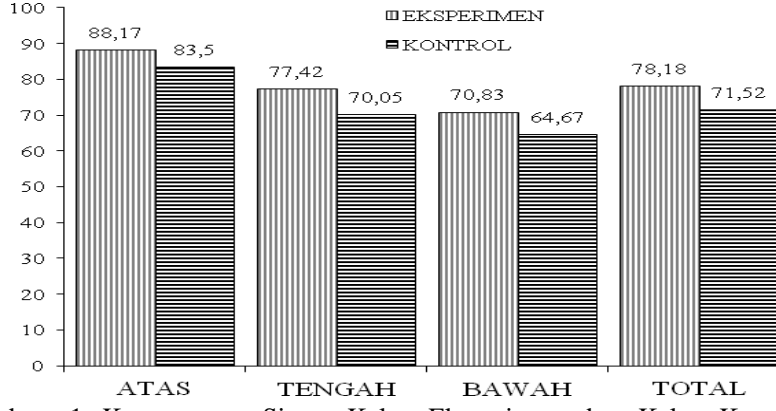

Gambar. 1 Kemampuan Siswa Kelas Eksperimen dan Kelas Kontrol berdasarkan Kelompok

Tampak pada Gambar 1 bahwa rata-rata kemampuan kemampuan komunikasi matematis kelas eksperimen lebih baik secara signifikan daripada kelas kontrol untuk semua kelompok, baik kelompok atas, kelompok menengah maupun kelompok bawah. Selain itu, kemampuan komunikasi matematis siswa berdasarkan kategori kemampuan pada kedua kelas penelitian secara ringkas dapat ditentukan berdasarkan Gambar 2. 


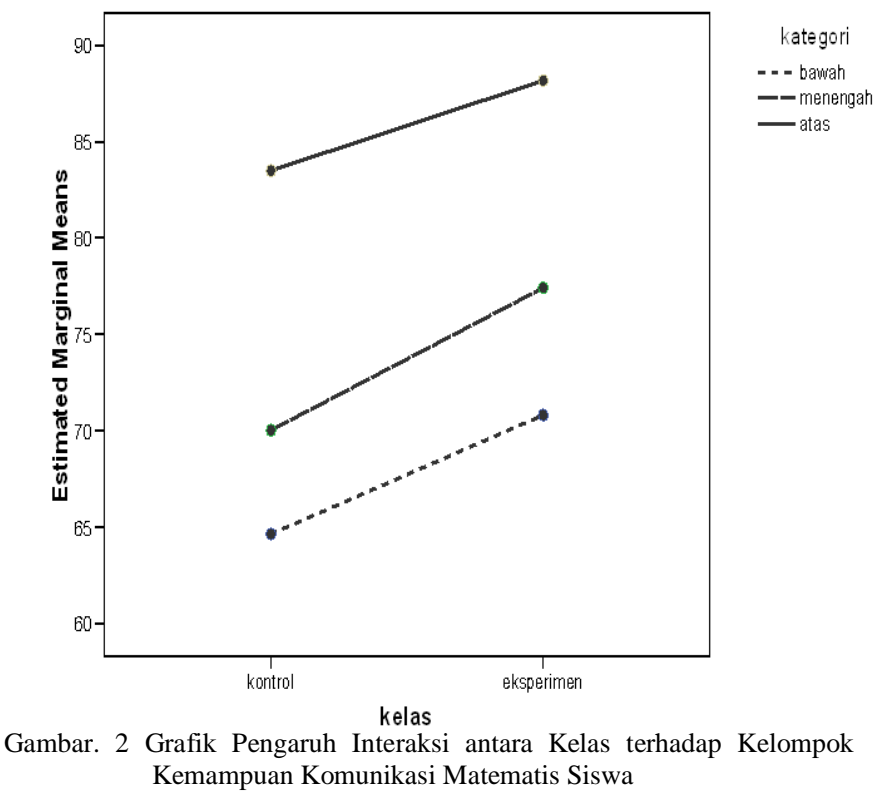

Berdasarkan Gambar 1 dan Gambar 2, dapat disimpulkan bahwa:

a. Kemampuan komunikasi matematis siswa kelompok atas pada kelas yang diajarkan menggunakan model kooperatif tipe CIRC berbasis konstruktivisme lebih baik dari kelas yang tidak diajarkan dengan menggunakan model tersebut.

b. Kemampuan komunikasi matematis siswa kelompok menengah pada kelas yang diajarkan menggunakan model kooperatif tipe CIRC berbasis konstruktivisme lebih baik dari kelas yang tidak diajarkan dengan menggunakan model tersebut.

c. Kemampuan komunikasi matematis siswa kelompok bawah pada kelas yang diajarkan menggunakan model kooperatif tipe CIRC berbasis konstruktivisme lebih baik dari kelas yang tidak diajarkan dengan menggunakan model tersebut.

d. Pada umumnya kemampuan komunikasi matematis siswa pada kelas yang diajarkan menggunakan model kooperatif tipe CIRC berbasis konstruktivisme lebih baik dari siswa yang tidak diajarkan dengan menggunakan model tersebut.

Analisa uji beda diperoleh hasil bahwa kemampuan komunikasi matematis pada kelas eksperimen dan kelas kontrol untuk kategori kelompok kemampuan atas, menengah dan bawah berbeda selanjutnya dilakukan uji banding dan diperoleh hasil bahwa kemampuan komunikasi matematis pada kelas eksperimen lebih baik dari kelas kontrol. Hal ini ditunjukkan dengan nilai rata-rata kemampuan komunikasi matematis pada kelas eksperimen adalah 78,182 sedangkan kelas kontrol 72,242. Kemampuan komunikasi matematis siswa pada kelas yang diajarkan dengan model CIRC berbasis konstruktivisme dan kelas yang diajarkan tanpa menggunakan model pembelajaran tersebut berbeda untuk tiap kategori kelompok atas, menengah dan bawah. Kemampuan komunikasi matematis siswa pada kedua kelas pembelajaran untuk kelompok atas lebih baik dari kelompok menengah dan dan bawah serta kelompok menengah lebih baik dari kelompok bawah. Selanjutnya kemampuan komunikasi matematis pada kelas yang diajarkan dengan model kooperatif tipe CIRC lebih baik dari kelas yang tidak menggunakan model tersebut. Hal tersebut sejalan dengan hasil penelitian Karimah (2013) bahwa "siswa yang mendapatkan pembelajaran kooperatif model CIRC mempunyai kemampuan komunikasi matematis lebih baik dibandingkan dengan menggunakan pembelajaran konvensional”.

\section{KESIMPULAN DAN SARAN}

\section{KESIMPULAN}

Berdasarkan hasil dan pembahasan maka simpulan pada penelitian ini sebagai berikut.

1. Kemampuan komunikasi matematis siswa pada kelas yang mendapatkan pembelajaran model kooperatif tipe CIRC berbasis konstruktivisme dapat mencapai ketuntasan minimal, baik secara individual maupun klasikal.

2. Kemampuan komunikasi matematis siswa dalam setiap kategori kelompok atas, menengah dan bawah pada kelas yang diajarkan menggunakan model kooperatif tipe CIRC lebih baik dari siswa pada kelas yang diajarkan tanpa menggunakan model tersebut.

SARAN

Berdasarkan simpulan maka dapat disarankan beberapa hal, sebagai berikut.

1. Model pembelajaran kooperatif tipe CIRC hendaknya dapat digunakan pada kegiatan 
pembelajaran

dalam

pembentukan

kemampuan komunikasi matematis siswa.

2. Hasil yang diperoleh bahwa kemampuan komunikasi matematis siswa pada kategori kelompok menengah dan bawah masih mengalami kekurangan pada indikator menyatakan gambar atau diagram ke dalam ide-ide matematika. Oleh karena itu perlu adanya pembimbingan khusus terhadap siswa secara ketat dalam proses pembelajaran terkait dengan menerjemahkan suatu gambar ke dalam ide matematika.

3. Bagi peneliti selanjutnya, dapat dijadikan sebagai referensi dan disarankan untuk perlu mengembangkan model pembelajaran kooperatif tipe CIRC atau model-model pembelajaran kooperatif yang lainnya pada materi geometri atau pada materi yang lain sebagai upaya dalam meningkatkan kemampuan komunikasi matematis siswa.

\section{DAFTAR PUSTAKA}

[1] Baroody, A.J. 1993. Problem Solving, Reasoning, And Communicating, K-8 Helping Children Think Mathematically. New York: Macmillan Publishing Company.

[2] Bicer, A., Capraro, R. M., \& Capraro, M. M. 2013. "Integrating Writing into Mathematics Classroom to Increase Students' Problem Solving Skills". International Online Journal of Educational Sciences, 5(2): 361-369.

[3] Capraro, R. M., Capraro, M. M., \& Rupley, W. H. 2011. "Readingenhanced word problem solving: A theoretical model". European Journal of Psychology of Education, 27(1): 91-114.

[4] NCTM. 2010. Curriculum and Evaluation Standard for School Mathematics. Reston: National Council of Teacher of Mathematics.

[5] Durukan, E. 2011. "Effects of Cooperative Integrated Reading and Composition (CIRC) Technique on Reading-writing Skills". Educational Research and Reviews, 6(1): 102-109.

[6] Karimah. 2013. "Pembelajaran Matematika Model Cooperative Integrated Reading and Composition (CIRC) untuk Meningkatkan Kemampuan Komunikasi Matematis Materi Segiempat Kelas VII”. DELTA, 1(2): 115-199.

[7] Suherman, E, dkk., 2003. Strategi Pembelajaran Matematika Kontemporer. Bandung: UPI.

[8] Ratnawulan, E \& Rusdiana, H. A. 2015. Evaluasi Pendidikan. Bandung: Pustaka Setia. 